\section{Is Corporate Governance Policy a New Paradigm for Social Responsibility? A Research Agenda from Ghana}

\author{
Alphonse Kumaza \\ Huazhong University of Science \& Technology, School of Management, China \\ kumaza1@yahoo.com
}

\begin{abstract}
Social responsibility has received great authorial comments on making business commitments compensatory for corporate profits and/or rent-seeking in host communities. Unfortunately, that voice remains silent on the fundamental component of business responsibility and its improvement, i.e., governance policy. The paper, consequently, recommends a corporate policy for equitable and compensatory corporate citizenship in local communities. To justify the proposition, three objectives are established: proof that social responsibilities can improve with a governance policy, that authoritative policy represents a crucial change in social initiatives execution, and that policy absence incentivises implementation ineffectiveness and commitments paucity. Triangulation of interviews and survey data through SPSS analysis shows statistically significant coefficients validating the claim that corporate governance policy is an enrichment and facilitator of social responsibilities. The proposed policy framework will not only deliver competitive, scientific, objective, and excellent services but also represent a novel and future academic investigation.
\end{abstract}

Keywords: corporate governance policy, corporate citizenship, social responsibility, externalities

\section{Introduction}

Corporate citizenship has caught the corporate community's attention, giving rise to business interventions in stakeholder societies. Though enterprises claim to be fully embedded in the social responsibility agenda, the implementation of programmes effectiveness and commitments suitability has remained in doubt. However, business roles in society have continued to increase and shape corporate commitments for external stakeholder constituencies. In Ghana, multinational enterprises are seen to be virtuous corporate citizens, as reports indicate engagement in one or two social activities for host communities; a claim Visser (2011) agrees with as being true of a top few large companies that engage in social responsibility. Therefore, that growing voice in support of better treatment of stakeholder communities by businesses can be meaningful and heard when the fundamental difficulty, i.e., a governance policy absence, is addressed. Alas, corporate governance injunction, i.e., recognising shareholders' rights and protecting stakeholders' interests, falls short of a recommendation for a governance policy for social interventions. For instance, it is contended that corporate governance tools must ensure wealth creation and profit maximisation and respect for the external stakeholder constituencies’ interest (Page, 2005).
ORIGINAL SCIENTIFIC PAPER

RECEIVED: OCTOBER 2018

REVISED: JANUARY 2019

ACCEPTED: JANUARY 2019

DOI: 10.2478/ngoe-2019-0001

UDK: 005.35:303.7(667)

JEL: G34, L53, M14

Citation: Kumaza, A. (2019). Is Corporate Governance Policy a New Paradigm for Social Responsibility? A Research Agenda from Ghana. Naše gospodarstvo/ Our Economy, 65(1), 3-15. DOI: 10.2478/ ngoe-2019-0001

\section{NG OE}

NAŠE GOSPODARSTVO OUR ECONOMY

\begin{tabular}{l|l|l} 
Vol. 65 & No. 1 & 2019 \\
\hline
\end{tabular}

pp. $3-15$ 
Meanwhile, it is acknowledged that internal systems of control and organisational management objectives (Cadbury, 1992; Cadbury, 2000) constitute the main drivers of governance principles to inspire a business-specific policy to manage the social responsibility imperatives. As a precursor, the governance structures must be deployed and devoid of problematic human realities to bring about innovation, progress, and economic benefits to business operating environments, i.e., the stakeholder communities.

Moreover, business prosperity hinges on sound and specific policies; without which, it is impossible for the enterprise's objectives to be executed. Therefore, corporate responsibility without a governance policy will imply failure, which also reflects the construct's careless implementation (Devinney, 2009). Unfortunately, CR is determined largely by business management, based on what it perceives as being good for major stakeholder communities. It is this human problematic reality that deserves attention and which should be addressed via the policy gap. The novel policy agenda is proposed to replace the current self-regulation strategy for social initiatives and environmental accountability. The replacement is crucial because self-commitment of social responsibilities is ineffective, insufficient, and less compensatory for corporate excessive profits from local communities.

The wide-ranging reforms institutionalisation within business bookkeeping practices for corporate compliance (Sarbanes, 2002) begins a serious dialogue between governance and responsibilities, in that businesses are now seen engaging in corporate accountability and environmental responsibility. This observed transformation enforces strict governance practices involving ethics, accountability, and disclosures, thus making social obligation an institution of governance and prioritising social objectives in corporate entities' decision-making arenas. Therefore, as the failure of system rules contributes less to corporate collapse and with problematic human realities being culpable, a business governance policy coupled with respect for rules can play a major role in upholding business objectives and social accountability.

The paper views the governance policy as the new standard in corporate responsibilities administration. The policy domain is novel and has to be explored further to make community engagement and environmental responsibility complete and compensate for business externalities.

The literature's corporate benevolence characterisation, discussions, and treatment of CR has muted interest in transforming the construct, undermining commitments for and projects in stakeholder communities. The paper, therefore, seeks to answer and advance corporate citizenship innovation proposition through queries, such as "Can corporate governance policy incentivise improvement in business accountability and environmental responsibility?" and "Is the policy distinction robust to reduce ineffectiveness and inadequacies in initiatives implementation?”

Besides, the overarching goal is to proffer insights into the novel governance policy to incentivise enhanced social responsibility and environmental accountability. The specific objectives include proof that social responsibilities through corporate governance policies can improve, and the validity that governance policy represents a crucial change in corporate responsibility implementation and its absence promotes commitments and interventions ineffectiveness and insufficiency for stakeholder communities.

Governance is a broad field to consider in a study; therefore, that aspect dictating the making of a plan is pursued. The corporate governance policymaking is viewed from directors' effective oversight roles in creating room for social policy to emerge and to be observed by other management staff for effective and enhanced social undertakings. Policy entails strategies made by corporate bodies to govern social agendas. Interviews for field data are costly and, hence, create a small data sample for analysis.

\section{Materials and Methods}

\section{Business Governance Construct}

Enterprise governance is a supervisory board and management system (Cadbury, 1992; Cadbury, 2000) and includes the conveyer belt for transmitting systemic mechanisms plus that which facilitates monitoring efficiency and effectiveness (Yang, McDaniel, \& Malone, 2012). Moreover, the organisation regulating aspect is also considered, which embodies agreement, accountability, and transparency in the laws (MacMillan, Money, Downing, \& Hillenbrand, 2004). Page (2005), however, focuses on the corporate governance aspect, which involves sanitising rules and regulations, safeguarding shareholders' rights and stakeholders' interests through corporate wealth management.

Suffice to infer, therefore, that business governance provides the organisational theme that defines a power structure and makes decisions and internalises corporate culture among its workers. However, governance rules underpinning the corporate body, in themselves, are different from that which constitutes and/or guarantees responsible corporate behaviour, value creation, commitment, and dedicated human capital. 
The recommendation that enterprises' pursuit of profits goes together with safeguarding stakeholders' interests (Sarbanes, 2002) is meant to ward off problematic human realities and the "agency problem" that ensues in business management; unfortunately, however, the institutionalisation came too late. The emphasis on stakeholder governance is resident in flaws inherent in shareholder corporate governance. The flaws include price measurement incapacitation of companies' performance and/or improvement and the compounding complications of markets' inadequate business externalities quantification, including pollution; short-term and passive investments; fraudulent share-based incentive schemes, which encourage huge benefits for top management and exploit stakeholders; plus gatekeepers' dishonesty-comprising auditors, rating agencies, securities market regulators, and independent directors - have all played parts to weaken shareholder corporate governance strength to champion sound and principled practices in business management and enforce respect for social values.

More persuasively, increasing social responsibilities acceptance in corporate management discourse might perhaps be attributable to shareholder governance shortcomings to limit business externalities. Therefore, while the Sarbanes-Oxley Act, which emphasises wide-ranging bookkeeping reforms for companies and failure to comply attracts severe penalties, seeks to transform corporate governance practice, the innovation is, at best, piecemeal against systemic and holistic change.

The rise in demand for good and sound practices in the business management of late is the recent high-profile financial crises domiciled in corporate administration. It is also noted that financial management and its reporting malfunction is resident in regulatory negligence and governance decay in corporate management. DeFond and Francis (2005) observe that the breakdown of this magnitude strengthens strict monitoring regimes, including improved board's oversight responsibility and robust scrutiny plus governance practices effectiveness (Sarbanes, 2002) to forestall funds mismanagement and encourage corporate accountability and social responsibility.

Again, a board's appointment and firing role promote good financial reporting, laws, standards, and norms plus enterprise effectiveness against problems that often ensue in business management. For an effective corporate governance system, board composition and ethics are paramount components (Boo \& Sharma, 2008; Krishnamoorthy, Wright, \& Cohen, 2002; Collier \& Gregory, 1996; Menon \& Williams, 1994) in making audit committees active and proactive in their work (Abbott, Parker, \& Peters, 2002). An enterprise's financial reliability, value reporting system, and regulations protection plus legal exposures from disrepute are based on board and audit committees' ability to uphold and strengthen stockholders' interests and corporate objectives (Carcello, Hermanson, \& Neal, 2002).

Meanwhile, championing stakeholder interests is effective through respect for social values, setting out detailed strategies for social programmes and encouraging boardroom decision-making. By respecting social values and environmental objectives, the enterprise is strengthened to achieve progress because consumer confidence is assured. Influencing management programmes and social initiatives means corporate governance policy can work to promote stakeholder interest.

Tying management incentives and remuneration to compliance with social aspirations and environmental accountability is another significant way to promote stakeholder concerns. This will ensure long-term investment interest against those premised on quick financial rewards, most often achieved at a great cost to society and the environment.

Compliance with systemic rules plus adherence to prudent governance practices is another means by which corporate governance effectiveness is demonstrated. Governance structure absence, i.e., the power of influence localised in a few directors, in enterprises results in principles collapse. Therefore, sound governance practices must go alongside appropriate power, management, and functions delineations (definitions) to avoid failures.

Leadership controls and internal rules for collective compliance by all in the organisation ensure corporate governance effectiveness. In effect, weak corporate leadership relaxes and weakens internal regulations and laws, processes, and procedures, leading to inefficiencies in organisational management. To envision and make policies and strategies for developing business needs is usually circumscribed by a lack of foresight. Therefore, competent and experienced leadership for organisations is an asset and allows for rules to benefit social initiatives.

An enterprise system of governance involves a multilayer authority outside management and whose responsibilities affect the organisation. This critical mass includes departmental heads who use internal rules in their functions. Constituting an organisational frontier, this group tracks business activities, identifies potential risks, and designs strategies to prevent such threats. As business management entrenches corporate governance, social accountability and environmental responsibility are poised and/or destined to be promoted. It behooves governance principles to create the appropriate and conducive atmosphere for a governance policy to emerge and oversee social responsibility implementation. The governance policy is needed because 
concomitant literature appraisal reveals social accountability and environmental governance policy non-existent and, thus, becomes the research problem gap to fill.

\section{Governance Policy and Self-Regulation Scrutiny}

A policy is comprehensive actions (Agbor, 2016; Smith, 1976; Hill, 1997) dictating long-term organisational objectives (Rue \& Ibrahim, 1998). Though a policy represents decisions and strategies for operationalising organisational objectives, it must be formulated by an authority or with such powers emanating from the highest level of authority.

A governance policy absence for CR makes corporations adopt a self-regulation strategy to police their own operations. Self-regulation is social objectives' self-determination for stakeholders, and such undertakings and/or interventions are mere decisions unsupported by organisational power and authority, leading to initiatives failures.

The strategy becomes attractive to corporations, especially mining transnational conglomerates, representing interests of powerful international economies and supported by pro-liberal global North governments. Because of the prohibition of national laws to police corporate behaviours, businesses have self-regulated their activities for their own benefits rather than those of the stakeholder communities. This has also incited contestation of corporate roles in social change agenda, evidencing Friedman's proposition or claim that business objective function is to maximise profits and create wealth for its stockholders (Friedman, 1970), a position this paper views as illogical, fallacious, absurd, and deficient, considering corporations' enhanced public roles in recent times.

Studies show that transnational conglomerates' participation in social responsibilities has emboldened and encouraged them to engage in large-scale bad practices, underscoring widespread ecological destruction and social costs (Aid, 2004a, 2004b). The foregoing instance corroborates the claim that recommendations, sets of initiatives, and guidelines established are unheeded to (Visser, 2011).

The apparent self-regulation weakens governance strategy for business social undertakings, in that the enterprise governance system has failed to nurture policy development for CR objectives. Policy postulation is critically significant to make social responsibility and environmental accountability work for stakeholder communities' stability. Therefore, the basis for governance institutions to provide platforms for social discourse toward policy space to oversee business operating environments needs delivery.
Again, the self-regulation encourages easy target setting and deprives host communities of quality and compensatory services. Thus, the claim that corporations meet their corporate citizenship objectives is misleading, complicates matters, and demeans the social change agenda. However, a governance policy provides room for the host community's representation and to influence adequate and appropriate corporate commitments.

More so, the governance programme strategy corroborates Heald's (1970) proposition that businesses should situate corporate accountability in real policies to achieve tangible impacts. Besides, the evidence of corporate involvement in externalities and labour exploitation (Aid, 2004b) has received a great authorial investigation. Therefore, the governance policy distinction provides a pathway for enhanced, quality, equitable, and balanced stakeholder services to reduce the complex complications of markets inadequate measurements of business externalities. It will make commitment cross-checking easier, provide communities with good and standard services, and enable exact and systematic governance while influencing initiative visibility. Governance policies allow social obligation agendas to be planned and encourages transnational businesses operations monitoring.

\section{Social Responsibility Construct}

Authorial accounts on corporate citizenship have been varied with extensive exposition, but Carroll's (1979) work is widely cited in the construct's discussion. Rahman (2011) observes that corporate responsibility decisions transcend primary economic and technical goals while recognising the construct's fluidity and proposes handling it in a managerial context. It is claimed that the responsibility agenda predicates on long-term commercial benefits for the firm (p. 70). Heald (1970) argues that corporate responsibility must be demonstrated in real policy frameworks. By this, a reference is made to community-oriented programmes and business executives who are predominantly preoccupied with corporate philanthropy and community relations. Johnson (1971), however, defines a socially responsible enterprise as one that declares huge profits and satisfies employees and other stakeholder's needs, along with stressing that business social obligation is the pursuance of socio-economic goals through elaborate practices approved and implemented by the business.

Moreover, the Committee for Economic Development opines that business establishment is granted by public authority and its purpose is social values and needs protection. CED further indicates that the social agreement is undergoing a crucial transformation and that enterprises are expected to 
take charge of social responsibilities and to serve wide-ranging human values. In its roles, a business should contribute substantially to improve social living standards and satisfy public expectations.

Further, CSR is considered a business desire to act in an ethical manner and contribute its quota to society, improve workforce and families' living standards, and ensure sustainable communities. Similarly, it is a standpoint comprising (a) considering and managing social and environmental impacts, (b) pursuing and creating opportunities, and (c) an “enlightened self-interest” approach to normalising stakeholder interests in corporate governance.

To delineate corporate citizenship boundaries, Carroll (1991) establishes a four-level CSR principle for a business. The economic principle relates to a business productive capacity to produce, create job opportunities, and ensure optimal wages. To achieve these value creation objectives, other resources, including technology, are deployed. As production proceeds beneficiaries, a business must fulfill tax obligations and other sovereign duties for developing an infrastructure in the incorporated country. Therefore, business economic responsibility is about delivering products and remaining profitable. Indeed, seven economic activities are delineated, which include satisfying customers with real value commodities; earning profits for investors; creating new wealth; promoting social values (as their wages rise) through new jobs; defeating envy; treating people equitably and improving lives; promoting innovation; and avoiding majority poor and underprivileged exploitation (Novak, 1996).

It is necessary that laws regulate business behaviour because corporations cannot be trusted for acting lawfully, hence the basis for legal responsibility. However, laws have limited scope and cover only what is known and about to happen because human actions determine the present circumstance of the law, and mere legal minimum provision for business' conduct (which are reactive, instructing direction to do things) is inadequate.

Again, ethical responsibilities cover people's moral rights, which are exercised (N. C. Smith \& Quelch, 1993) and include social norms, institutions, and decisions, either expected (positive) or prohibited (negative), in society, although they are not written laws (Carroll \& Shabana, 2010). These injunctions, therefore, constitute a business's ethical obligations in stakeholder communities. Nowadays, society disregards productivity as moral justification for business wealth generation but noneconomic effects on society, among which are the employee and the customer welfare systems, stakeholders, and business operating environments.
Discretionary obligations are voluntary services that compensate people and societies because corporations operate in communities, and their activities have an impact on social values. Businesses are considered good citizens not by economic performance but social contributions that lift the poor from poverty and squalor. The engagement contract is changing ... and businesses must serve wide-ranging social needs (Chewning, Eby, \& Roels, 1990).

That corporate decision-making negatively affects communities and lives supports business social expectations and specific business decision-makers' responsibilities (Beuachamp \& Bowie, 1983) because it has links with people's welfare and better living standards. The thinking by Chewning (1990) that the enterprise is a social institution makes it imperative for corporations to join hands and build structures, and amongst such social institutions is the family for improvement of economic conditions. The modern corporate world is characterised by professional managers whose decisions have an impact on communities (Miller, 1993) while exploiting societal resources to enrich corporate industrial objectives.

A growing consensus, therefore, suggests that business must assist in solving corporate externalities because enterprise taxes alone are insufficient (Jamal \& Bowie, 1995) to ameliorate appalling environmental pollution and other externalities. Indeed, businesses possess massive economic resources, including know-how and financial power (Lippke, 1996), to develop host communities if one wishes.

\section{Method}

The technique deployed here aims to project the scientific assumptions and strategies, thus situating the study among research traditions. Specifically, focused interview procedures for relevant field data gathering are used, and the information is used to develop a questionnaire for the study's population. The study deploys an SPSS statistical package (Spearman's correlation and regression) for analysis. The online system provides secondary information as a baseline for empirical data gathering, without which field data collation is difficult.

The investigation conduct interviews for mining transnational conglomerates' representatives selected. These enterprises include the population from which individual management, namely, David Johnson, stakeholder relations, West Africa, and his two deputies responsible for corporate affairs plus other departmental heads (Goldfields Ghana); the corporate affairs head, including other senior management manning security, environment, and human resources (Asanko Gold Ghana); and the president and his vice plus 
other departmental heads managing environment, human resource and security portfolios (Golden Star Resources).

However, the investigation also gathers individual-level data, from the community opinion leaders, community-based environmental institutions representatives, plus nongovernmental actors in mining exploration and development, aimed at authenticating and cross-referencing the company-level data obtained.

Focused/semistructured interview techniques are used to gather field data because they enable thorough scrutiny and encourage the investigation to interview details and processes. The field interviews help the investigation to reflect dimensions and objects for thorough understanding. The enterprise-level data are obtained based on questions, including mining impacts on life and property. This information aims at discovering an enterprise's management understanding for ramifications resulting from its prospecting activities, the safeguards, and/or strategies adopted to curb these challenges. Information on community support and future considerations are also pursued. The investigation used prepared questions, subsequently altered to accommodate response dynamism.

To validate and cross-examine the company-level data, the investigation interviewed 50 key participants. Though the individual-level information is merely aimed at cross-referencing the corporate data, it legitimises the data collation process and empowers the investigation to identify misleading responses for reconciliation.

This data-gathering technique gives freedom to the investigation to decide the manner and questions' sequence in the interview processes, and decisions to explore reasons and motive aimed at confining respondents' familiar issues. In general, therefore, this method is deployed in the proposition to constitute unstructured interviews. Indeed, it benefits the investigation by allowing complete data gathering with much precision for questionnaire design and credibility for findings. Again, personal involvement and/or contact with respondents increases response rates and, more so, allows the investigation to have more order and flow of questions. It also helps the investigation to introduce necessary modifications in the scheduled interviews based on initial results, which is not possible when conducting only a survey study without early interviews.

Further, the interview methods offer the investigation a chance to discover data, which is often difficult using only questionnaires and/or participant observation (Blaxter, Hughes, \& Tight, 2006). It also allows the research to generate real-life and authenticated data, which is universally acceptable. Besides, this technique is crucial in objectives setting (Hamel, Dufour, \& Fortin, 1993; Yin, 1994) underscoring its use in this research.

There are, however, a few shortcomings in using this data-gathering methodology, which include biases resulting from fatigue in dealing with large participants and the investigation becoming involved with the interviewees. Data generated from qualitative interviews are huge and overwhelmingly voluminous (Neuman \& Robson, 2007), and an hour interview may produce gigantic data, which can take several hours or days to transcribe (Dörnyei, 2007). Challenges of potential bias in generating information via interviews are possible, yet it is deployed for small-scale studies.

The investigation pretested the questionnaire for 10 respondents to enable corrections (if any). The pilot informs and guides the investigation in the questionnaire administration to the target research audience. In all, 50 questionnaires are served but 40 returned answered, which is a better response rate.

The research uses Spearman's correlation statistical technique in analysing the survey data because it establishes a paired data relationship, symbolised $\mathrm{Sr}$, which is inhibited as follows:

\section{$(-1 \leq S r \leq+1)$.}

The above is interpreted as, the closer Sr, the stronger the monotonic relationship. Correlation is thus described by strength and size, indicating $\mathrm{Sr}$ as an absolute value. In calculating coefficients for the study, no requirement is made of normality, hence a nonparametric correlation statistic is used. Though the method presents relationship strength in two constructs (i.e., it allows for predictions about variables under consideration; uses for wide-ranging phenomena [fictions and nonfiction], and deploys for sample data $[N]$ more than 30), the technique is limited and can create room for biases, especially where high correlation exists and produces misleading information. The bias is experienced because a strong variables relationship does not always mean robust measures agreement.

Additionally, the study employs a regression method for predictors and unknown variables determination. This technique deployment, as an SPSS statistical package, stems from its measure to show causal relationships within and among variables. Meanwhile, as a statistical prediction tool, predicting variables, given the other when those variables are inter-related, it shows a mathematical average variables relationships measurement and, as such, includes a measure that predicts unknown variables from a known one. It estimates dependent variables from independent ones and also shows errors involved. 
More so, regression helps in identifying correlations, and an actual relationship enables value estimation for which it is valid. The variables' relationships remain the same until the calculations are completed. While dependent variables assume any value taken at random, independent ones are fixed. Calculating regression involves one reliant measure but many independent variables. Research indicates that the method only gives confidence levels to the investigation that the predictions are okay except proving the claim.

In the nutshell, a mixed method is deployed for data gathering. Thus, the triangulation approach is vindicated and accredited for integrating enquiry that combines techniques (Denzin, 1970, 1992). Indeed, it becomes an excellent beginning for empirical research and receives a more authoritative acknowledgment (Sayer, 2000; Danermark, Ekström,
Jakobsen, \& Karlsson, 2002) and enables the investigation to use wide-ranging methods to dissimilar phenomena.

\section{Hypotheses}

This paper's overarching objectives, similar assumptions, and theories advanced to provide the basic suppositions and/ or principles are to be verified via the following assumptions:

H1: Corporate governance policy correlates with business accountability and environmental responsibility.

H2: Business governance policy for corporate accountability makes enterprise commitments adequate and ensures effective implementation.

\section{Research Model 1}

Figure 1. Strong Corporate Governance System (A)

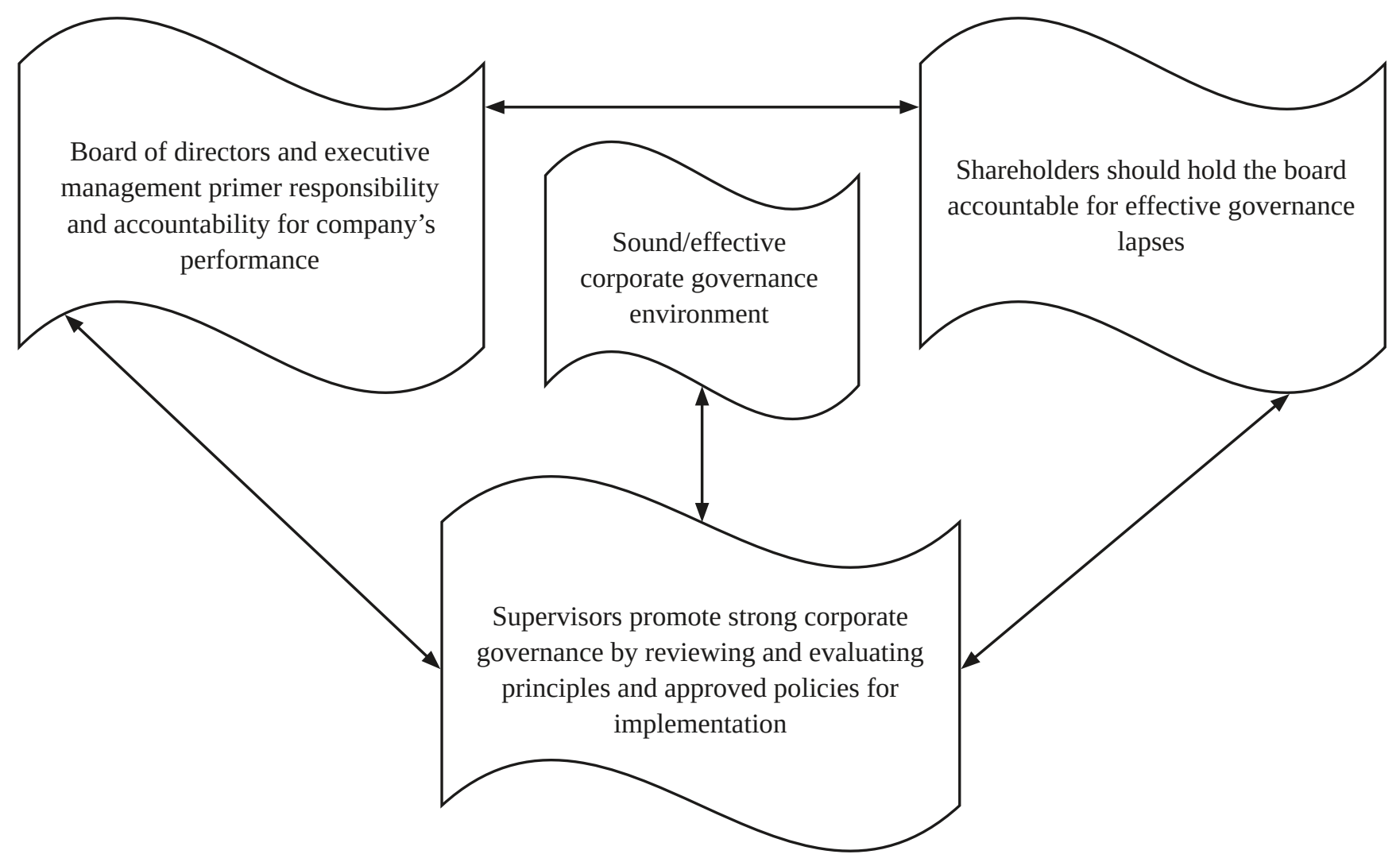

Source: Author 


\section{Research Model 2}

Figure 2. Corporate Governance System (B)

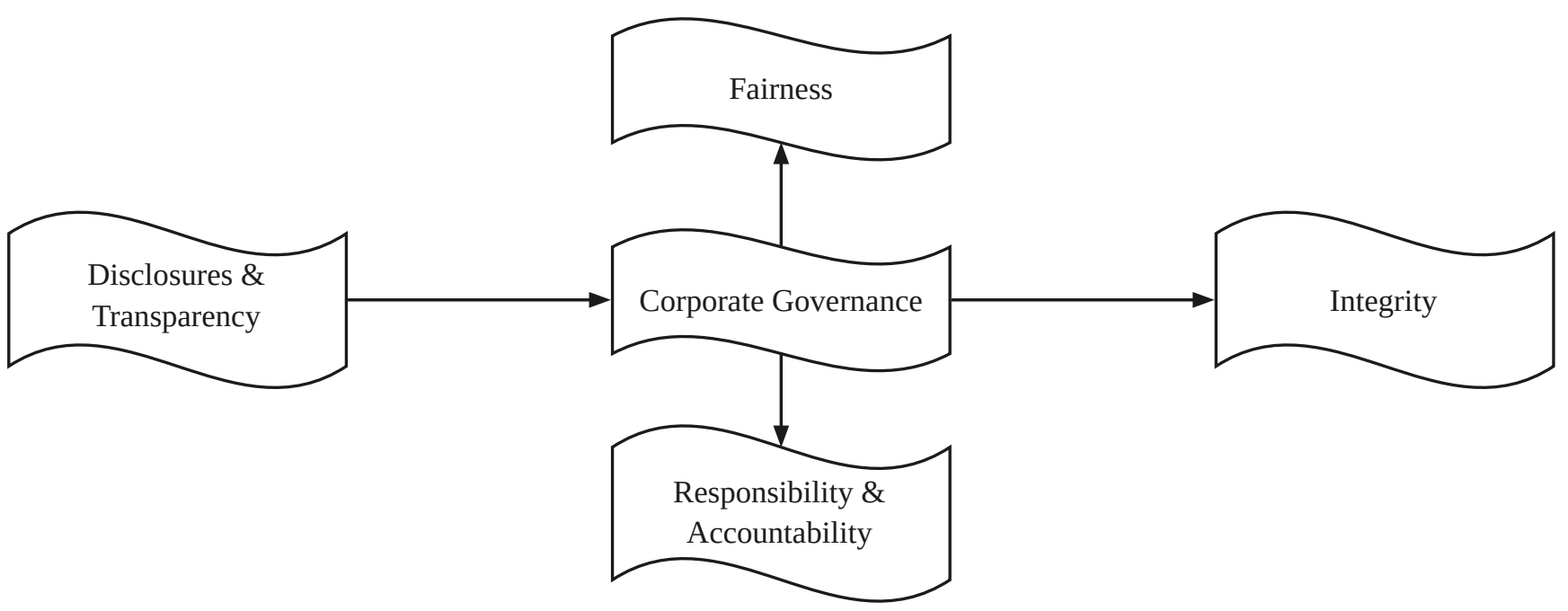

Source: Author

The corporate governance models, which are shown in Figures 1 and 2, explain the board of director's oversight functions through chief executive officers right down to junior management staff in an organisation's routine activities to achieve results. The respect for organisational rules and regulations are paramount to achieving stated objectives, which is a key ingredient in governance principles.

\section{Results and Discussion}

The demographic variables indicate respondents' stratification (as male and female) and their agreement percentages with specific questions. Male constitutes 42.5\% ( $n=17)$, while $57.5 \%(n=23)$ is female for whole population (40). In all, the respondents' agreement with questions reflect questionnaire acceptance and, therefore, makes it viable and valid for use.

Table 1. Questionnaire Consistency Indicators

\begin{tabular}{lccc} 
Measure & $\begin{array}{c}\text { Cronbach's } \\
\text { Alpha }\end{array}$ & $\begin{array}{c}\text { Cronbach's Alpha- } \\
\text { Standardised Items }\end{array}$ & N \\
\hline CR & .916 & .933 & 4 \\
\hline CG & .883 & .867 & 7 \\
\hline POL & .925 & .937 & 7 \\
\hline
\end{tabular}

Note: $\mathrm{CR}=$ Corporate Responsibility, $\mathrm{CG}=$ Corporate Governance, POL=Policy, $N=$ Number

Table 1 is a reliability statistic assessment for the questionnaire, which explains internal computation dependability. The statistic values (.883, .916, and .925) for CG, CR, and policy, respectively, are outstanding coefficients and, therefore, make the questionnaire highly reliable to be used for the study.

Additionally, a multi-item scale helps in accuracy, applicability, and scale quantification (Pandey, 2009). The Cronbach's alpha is deployed because it defines the questionnaire's internal reliability and its ability in determining internal and ratio scales, while an established guideline (George \& Mallery, 2003; Gliem \& Gliem, 2003) describes variables' consistency and reliability under discussion. Again, an alpha value gives an indication that variables are accepted (Malhotra, Kim, \& Agarwal, 2004) and inferences can be made, too.

Table 2. Descriptive Statistics

\begin{tabular}{lccc} 
Item & Mean & $\begin{array}{c}\text { Standard } \\
\text { Deviation }\end{array}$ & $N$ \\
\hline CR total & 10.3750 & 3.71889 & 40 \\
\hline CG total & 25.9250 & 4.68159 & 40 \\
\hline POL total & 20.9750 & 4.43464 & 40 \\
\hline
\end{tabular}

Note: CR=Corporate Responsibility, CG=Corporate Governance, POL=Policy, $N=$ Number

Table 2 shows the group total descriptive statistics. In the test analysis, CSR, CG, and policy totals show a little spread, indicating variables' inconsistency, which meets the validity criterion and makes the constructs support the study's proposition.

The research aims are, first of all, to produce proof that governance policy can improve social accountability and environmental responsibility; second, the policy distinction represents a novel arena for business commitment 
Table 3. Correlations for Group Total

\begin{tabular}{|c|c|c|c|c|c|}
\hline & \multicolumn{2}{|c|}{ Group Total } & \multirow{2}{*}{$\frac{\text { CR Total }}{1.000}$} & \multirow{2}{*}{$\frac{\text { CG Total }}{.628^{* *}}$} & \multirow{2}{*}{$\frac{\text { POL Total }}{-.332^{*}}$} \\
\hline & & Correlation Coefficient & & & \\
\hline & CR total & Sig. (2-tailed) & . & .000 & .036 \\
\hline & & $N$ & 40 & 40 & 40 \\
\hline & & Correlation Coefficient & $.628^{* *}$ & 1.000 & $-566^{* *}$ \\
\hline \multirow[t]{5}{*}{ Spearman's rho } & CG total & Sig. (2-tailed) & .000 & . & .000 \\
\hline & & $N$ & 40 & 40 & 40 \\
\hline & & Correlation Coefficient & $-.332^{*}$ & $-.566^{* *}$ & 1.000 \\
\hline & POL total & Sig. (2-tailed) & .036 & .000 & . \\
\hline & & $N$ & 40 & 40 & 40 \\
\hline
\end{tabular}

Note: $\mathrm{CR}=$ Corporate Responsibility, CG=Corporate Governance, POL=Policy

**Correlation is significant at the 0.001 level (2-tailed).

*Correlation is significant at the 0.05 level (2-tailed).

Table 4. Regression Coefficients ${ }^{\mathrm{a}}$

\begin{tabular}{|c|c|c|c|c|c|c|}
\hline \multicolumn{2}{|c|}{ Model } & \multicolumn{2}{|c|}{ Unstandardised Coefficients } & \multirow{2}{*}{$\begin{array}{c}\text { Standardised } \\
\text { Constants } \\
\text { Beta }\end{array}$} & \multirow[t]{2}{*}{$t$} & \multirow[t]{2}{*}{ Sig. } \\
\hline & & B & Standard. Error & & & \\
\hline & & 6.636 & .655 & & 10.136 & .000 \\
\hline \multirow{3}{*}{1} & Board effectiveness favours business \& CR & -1.068 & .148 & -678 & -7.229 & .000 \\
\hline & CR committee independence is doubted & -432 & .085 & -.558 & -5.059 & .000 \\
\hline & $\begin{array}{l}\text { Sustainability company incorporates sustainable } \\
\text { values in its operations }\end{array}$ & .500 & .054 & 1.065 & 9.258 & .000 \\
\hline
\end{tabular}

a. Dependent Variable: Lack of a policy for CR governance results in corporate carelessness, irresponsibility, and unaccountability for its actions.

implementation; third, the policy framework absence is at the heart of CSR projects failures. The above-mentioned goals are to be explored in the ensuing deliberations to proffer solutions to queries, such as "Can corporate governance policy incentivise improvement in business accountability and environmental responsibility?" and "Is the policy distinction robust to reduce ineffectiveness and inadequacies in initiatives implementation?”

Table 3 shows $p$-value $(p<.001)$ and negative coefficient $\left(-.566^{* *}\right)$, which shows a strong policy agreement with corporate governance. This means that corporate governance can support a policy framework for social accountability and environmental responsibility. Again, at a $p$-value .036, an association (-.332*) exists between policy and CR, which reflects current policy lack for $\mathrm{CR}$, and a validation for policy nuance application to social commitments. Additionally, a $p$-value $(p<.001)$ occasions positive comparability $\left(.628^{* *}\right)$ between CR and CG, signifying that governance can promote social responsibility through a policy space creation.

The CR, CG, and policy interplay reveal symbiosis among the constructs, which validate the suppositions that social responsibilities can be improved via business governance policy and represent fresh ground for corporate responsibility implementation; yet, its absence promotes commitments and intervention ineffectiveness and insufficiency for the stakeholder communities. This is, therefore, sufficient grounds to infer that an enterprise governance policy incentivises improvement in business accountability to stakeholders, and policy distinction is a robust platform to reduce ineffectiveness and inadequacies in initiatives implementation.

Heald (1970) recognises impracticality self-regulation as a vehicle for social accountability and environmental responsibility and calls for situating CR in the actual policies to deliver material social impacts. This suggests that initiatives undertaken by transnational conglomerates can improve only if the execution is done through a purposive governance policy framework because the policy distinction will provide standards and benchmarks to avoid management inertias and idiosyncrasies.

Frynas' (2005) concern for commitment ineffectiveness and inadequacy to meet desired social demands is dispelled by the findings that policy application will promote social intervention effectiveness. This, therefore, sustains the claim that 
self-regulation and/or self-commitment strategies for implementing initiatives for and in stakeholder communities are unfeasible, sporadic, and impromptu and deliver little or lead to significant project failures. The challenge, thereof, brings to sharp focus haphazard and unsystematic programmes implementation, which leads to stereotype maintenance involving commitments being adjudged by corporate management, i.e., an approach that undermines commitments' effectiveness and adequacy. No wonder that huge evidence shows corporate involvement in cost externalisation and labour exploitation (Aid, 2004; Malan, 2005; Pakenham, 1992; Armstrong, 2005; Tolhurst, 2010; Visser, 2010).

The result also vindicates Auty's worries that developing countries' capacity to harness mineral wealth and build social capital is constrained because the national policy is nonexistent. The Glencore-Xstrata merger (which controls the zinc and copper deposits) accrues $\$ 70$ billion profits to the mining conglomerate, yet the resource country, the D.R. of Congo, receives nothing from this windfall, demonstrating how little benefit there is for the resource owners.

Deductively, the evidence adduced social responsibilities and environmental accountability scantiness, which validate the notion that corporate citizenship is used as a promotional tool to elicit corporate legitimacy, which is a good image for increased profits and improved financial outlook. Similarly, studies and/articles scrutinise rigidities (tensions) in private business, self-regulating social and environmental objectives while stressing challenges involved in building and sustaining support for such initiatives among different national industry groups (Conzelmann, Wolf, Graz, \& Nölke, 2007) and commitments' inadequacies for host communities (Frynas, 2005).

Table 4 contains the value of each term, statistical tests for the constructs, and the coefficients. The $p$-value (.001 x 3) is statistically significant, while the predictor is prominent and ought to be interpreted because the predictor's value is related to response variables changes. That the selected variables indicate statistical significance mean abundant evidence to believe the constructs are monotonically correlated and, therefore, validate the studies objectives. Additionally, $t$-values $(-7.229,-5.059,9.258)$ also display little significant variation to data sample, which indicates constructs have high comparability and authenticate the study's predictions. Likewise, standard error coefficients (.148, .085, and .054) show insignificant values, which indicate the observations are closer to the preferred fitted line and thus support the research expectations.

The above, therefore, means a conclusion can be drawn that a governance policy absence leads to corporate carelessness and irresponsibility in meeting stakeholder needs.
Moreover, studies show that the apparent little corporate engagement in social accountability leads to far-reaching business “irresponsibility” (Frynas, 2005; Banerjee, Chio, \& Mir, 2009), thus underscoring temptation to describe CSR as an oxymoron for the "carelessness" it has been handled with (Devinney, 2009). The finding further shows the current self-regulation, through which social amenities are delivered by transnational enterprises, is an inappropriate strategy, which validates the policy distinction recommendation and subsequent application to CSR. In this way, the governance policy proposition is thus understood to benefit business, social accountability, and environmental responsibility. For corporations, it gives proof of good corporate citizenship, while governance policy improves social accountability and respect for norms, precepts, and values. Heald (1970) supports the governance policy proposal by noting that corporate commitments must be situated in and backed by a policy to deliver material social impacts.

Meanwhile, a unit change in the model's constant (6.636) will lead to this measure $(-1.068)$ of change in board effectiveness, which favours business and CSR. Likewise, one unit change of the model's constant (6.636) will lead to measure adjustments (-.432 and .500) and confirm CSR committee independence is doubted and that sustainability in a company incorporates sustainable value in its operations, respectively. The result demonstrates that significant evidence exists to believe governance policy would improve and promote corporate commitments and undertakings and to forestall business irresponsibility and unaccountability.

This implies that governance policy ensures systematisation, planning effectiveness, and interventions execution, best practices, benchmarks, and increased programmes visibility while providing the basis for subjecting management's idiosyncratic decisions to scrutiny. Indeed, the proof provided in this paper justifies the claim governance policy is an innovation for and in business accountability to its stakeholder constituencies and the environment.

\section{Conclusions}

Business roles in society have escalated because they benefit corporations while ensuring socially stable communities and environmental accountability. In this context, a dialogue is emerging between public authority and corporate power in regard to the appropriate method of collaboration to motivate mutual respect and gains. Unfortunately, the fundamental element is mistakenly ignored; that is, a governance policy for the social transformation agenda. The paper advocated for a governance policy to oversee corporate commitments and environmental accountability because it will provide the 
life wire for corporate citizenship resuscitation and makes business pledges' implementation effective and efficient.

It is empirically proven that a governance policy promotes and improves social responsibilities through eliciting corporate sincerity, limiting management inertias and idiosyncratic problematic human realities, while acting as a new paradigm shift in corporate citizenship delivery. This very thinking prompts the argument that corporate citizenship must be located in and supported by an actual business policy to produce quantifiable, collective, societal effects (Heald, 1970).

Interviews and survey data are measured via an SPSS statistical technique (involving Spearman's correlation and regression) for analysis. This is because the pluralism method, having been justified and credited for integrating research (Denzin 1970, 1992), enables investigation into wide-ranging procedures to the dissimilar phenomenon. Funding remains a big challenge, especially as interviews for on-site information and/or data collation are usually expensive, resulting in small and limited data for analysis.
In a nutshell, the paper suggests examining business responsibility and environmental accountability through governance policy perspective to establish suitable methods for governance policy parameters operationalisation and to provide future academic enquiry.

\section{Acknowledgment}

My gratitude goes to David Johnson, Stakeholder Relations, and his two deputies responsible for corporate affairs (Goldfields Ghana); Adelaide Boye (Mrs.), corporate administration manager, African Mining Services, Accra Office; Corporate Affairs of Asanko Gold Ghana; and the president and his vice of Golden Star Resources, Ghana for interviews and survey data gathering. I am also indebted to my beautiful daughter, Caitlyn Edudzi Mic-Kumaza, for being my inspiration on this long journey. I recall times that my leaving Ghana back for school (in China) made her cry. To all whose names did not appear, I say a big thank you. To God Be the Glory.

\section{References}

Abbott, L. J., Parker, S., \& Peters, G. F. (2002). Audit committee characteristics and financial misstatement: A study of the efficacy of certain blue ribbon committee recommendations. Retrieved from https://papers.ssrn.com/sol3/Delivery.cfm?abstractid=319125 http://dx.doi.org/10.2139/ssrn.319125

Agbor, S. (2016). An appraisal of open system business policy models in the management of mission hospitals in South-South Nigeria. (Doctoral Dissertation).

Aid, C. (2004a). Behind the mask: The real face of corporate social responsibility. London: Christian Aid.

Aid, C. (2004b). Behind the mask: the real face of CSR. London: Christian Aid.

Armstrong, E. (2005). Integrity, transparency, and accountability in public administration: Recent trends, regional and international developments, and emerging issues. United Nations, Department of Economic and Social Affairs, 1-10.

Banerjee, S. B., Chio, V. C., \& Mir, R. (2009). Organizations, markets, and imperial formations: Towards an anthropology of globalization. Edward Elgar Publishing. https://doi.org/10.4337/9781848447226

Beuachamp, T., \& Bowie, N. E. (1983). Ethical theory and business. Englewood Cliffs: NJ: Prentice-Hall.

Blaxter, L., Hughes, C., \& Tight, M. (2006). How to research. Berkshire: Open University Press.

Boo, E. f., \& Sharma, D. (2008). Effect of regulatory oversight on the association between internal governance characteristics and audit fees. Accounting \& Finance, 48(1), 51-71. https://doi.org/10.1111/j.1467-629X.2007.00229.x

Cadbury, A. (1992). Report of the committee on the financial aspects of corporate governance, Vol. 1. London: Gee and Co Ltd.

Cadbury, S. A. (2000). The corporate governance agenda. Corporate Governance: An International Review, 8(1), 7-15. https://doi. org/10.1111/1467-8683.00175

Carcello, J. V., Hermanson, D. R., \& Neal, T. L. (2002). Disclosures in audit committee charters and reports. Accounting Horizons, 16(4), 291-304. https://doi.org/10.2308/acch.2002.16.4.291

Carroll, A. B. (1979). A three-dimensional conceptual model of corporate performance. Academy of management review, 4(4), $497-505$. https://doi.org/10.5465/amr.1979.4498296

Carroll, A. B. (1991). The pyramid of corporate social responsibility: Toward the moral management of organizational stakeholders. Business Horizons, 34(4), 39-48. https://doi.org/10.1016/0007-6813(91)90005-G

Carroll, A. B., \& Shabana, K. M. (2010). The business case for corporate social responsibility: A review of concepts, research, and practice. International Journal of Management Reviews, 12(1), 85-105. https://doi.org/10.1111/j.1468-2370.2009.00275.x

Chewning, R. C., Eby, J. W., \& Roels, S. J. (1990). Business through the eyes of faith. San Francisco: Harper Collins.

Collier, P., \& Gregory, A. (1996). Audit committee effectiveness and the audit fee. European Accounting Review, 5(2), 177-198. https://doi. org/10.1080/09638189600000012 
Conzelmann, T., Wolf, K. D., Graz, J.-C., \& Nölke, A. (2007). The potential and limits of governance by private codes of conduct. Transnational private governance in the global political economy, 98-114.

Danermark, B., Ekström, M., Jakobsen, L., \& Karlsson, J. C. (2002). Explaining society. Critical realism in the social sciences. London: Routledge.

DeFond, M. L., \& Francis, J. R. (2005). Audit research after Sarbanes-Oxley. Auditing: A Journal of Practice \& Theory, 24(s-1), 5-30. https:// doi.org/10.2308/aud.2005.24.s-1.5

Denzin, N. (1970). Strategies of multiple triangulation. The research act in sociology: A theoretical introduction to the sociological method, 297, 313.

Denzin, N. (1992). The many faces of emotionality: Reading persona. Investigating subjectivity: Research on lived experience, 17-30. Neubury Park: Sage.

Devinney, T. M. (2009). Is the socially responsible corporation a myth? The good, the bad, and the ugly of corporate social responsibility. The Academy of Management Perspectives, 23(2), 44-56. https://doi.org/10.5465/amp.2009.39985540

Dörnyei, Z. (2007). Research methods in applied linguistics: Quantitative, qualitative, and mixed methodologies: Oxford University Press.

Friedman, M. (1970). The Social responsibility of business is to make a profit. New York Times Magazine, 13.

Frynas, J. G. (2005). The false developmental promise of corporate social responsibility: Evidence from multinational oil companies. International Affairs, 81(3), 581-598. https://doi.org/10.1111/j.1468-2346.2005.00470.x

George, D., \& Mallery, M. (2003). Using SPSS for Windows step by step: A simple guide and reference (4 $4^{\text {th }}$ Ed.). London: Pearson Education.

Gliem, J. A., \& Gliem, R. R. (2003). Calculating, interpreting, and reporting Cronbach's alpha reliability coefficient for Likert-type scales. Retrieved from www.ijcmph.com/index.php/ijcmph/article/download/396/385

Hamel, J., Dufour, S., \& Fortin, D. (1993). Case study methods (Vol. 32): Sage. https://doi.org/10.4135/9781412983587

Heald, M. (1970). The social responsibilities of business: Company and community 1900-1960: New Brunswick: Transaction Publishers.

Hill, M. J. (1997). The policy process in the modern state: Prentice Hall PTR.

Jamal, K., \& Bowie, N. E. (1995). Theoretical considerations for a meaningful code of professional ethics. Journal of Business Ethics, 14(9), 703-714. https://doi.org/10.1007/BF00872324

Johnson, H. L. (1971). Business in contemporary society: Framework and issues: Belmont, CA: Wadsworth Pub. Co.

Krishnamoorthy, G., Wright, A., \& Cohen, J. (2002). Audit committee effectiveness and financial reporting quality: Implications for auditor independence. Australian Accounting Review, 12(28), 3-13.

Lippke, R. (1996). Setting the terms of the business responsibility debate, in Ethics in the workplace: Selected readings in business ethics, Larmer, RA (Ed), West Publishing Company, Minneapolis/St. Paul, MN. St. Paul, MN.

MacMillan, K., Money, K., Downing, S., \& Hillenbrand, C. (2004). Giving your organization SPIRIT: an overview and call to action for directors on issues of corporate governance, corporate reputation, and corporate responsibility.Journal of General Management, 30(2), 15-42. https://doi.org/10.1177/030630700403000203

Malan, D. (2005). Corporate citizens, colonialists, tourists or activists? Ethical challenges facing South African corporations in Africa. The Journal of Corporate Citizenship(18), 49. https://doi.org/10.9774/GLEAF.4700.2005.su.00009

Malhotra, N. K., Kim, S. S., \& Agarwal, J. (2004). Internet users' information privacy concerns (IUIPC): The construct, the scale, and a causal model. Information systems research, 15(4), 336-355. https://doi.org/10.1287/isre.1040.0032

Menon, K., \& Williams, J. D. (1994). The use of audit committees for monitoring. Journal of Accounting and Public Policy, 13(2), $121-139$. https://doi.org/10.1016/0278-4254(94)90016-7

Miller, T. (1993). The well-tempered self citizenship, culture, and the postmodern subject. Baltimore, Md.: Johns Hopkins University Press.

Neuman, W. L., \& Robson, K. (2007). Basics of social research: Qualitative and quantitative approaches. Power, 48, 48. Retrieved from https://www.pearson.com/.../Neuman-Basics-of-Social-Research-Qualitative-and-Quan...

Novak, W. J. (1996). The people's welfare: Law and regulation in nineteenth-century America: London: Univ of North Carolina Press.

Page, J.P. (2005). Corporate governance and value creation. University of Sherbrook, Research Foundation of CFA Institute. Retrieved from https://www.cfainstitute.org/-/media/documents/.../2005/rf-v2005-n1-3930-pdf.ashx

Pakenham, T. (1992). The scramble for Africa: White man's conquest of the dark continent: New York: HarperCollins Publishers.

Pandey, A. (2009). Understanding consumer perception of brand personality. Retrieved from https://www.ssrn.com/abstract=1441824 http://dx.doi.org/10.2139/ssrn.1441824

Rahman, S. (2011). Evaluation of definitions: ten dimensions of corporate social responsibility. World Review of Business Research, 1(1), 166-176.

Rue, L. W., \& Ibrahim, N. A. (1998). The relationship between planning sophistication and performance in small businesses. Journal of Small Business Management, 36(4), 24.

Sarbanes, P. (2002). The Sarbanes-Oxley act of 2002. Paper presented at The Public Company Accounting Reform and Investor Protection Act. Washington DC: US Congress.

Sayer, A. (2000). Realism and social science. London: Sage. https://doi.org/10.4135/9781446218730

Smith, B. C. (1976). Policy-making in British government: An analysis of power and rationality: Lanham: Rowman \& Littlefield Publishers, Inc.

Smith, N. C., \& Quelch, J. A. (1993). Ethical issues in researching and targeting consumers. Ethics in Marketing, 145-195. 
Visser, W. (2010). The age of responsibility: CSR 2.0 and the new DNA of business. Retrieved from https://www.researchgate.net/ publication/228188599_The_Age_of_Responsibility_CSR_20_and the_New_DNA_of_Business

Visser, W. (2011). The age of responsibility: CSR 2.0 and the new DNA of business. London: John Wiley \& Sons.

Visser, W., Matten, D., Pohl, M., \& Tolhurst, N. (2010). The A to Z of corporate social responsibility. London: John Wiley \& Sons.

Yang, J. S., McDaniel, P. A., \& Malone, R. E. (2012). 'A question of balance': Addressing the public health impacts of multinational enterprises in the OECD Guidelines for Multinational Enterprises. Global public health, 7(10), 1045-1061. https://doi.org/10.1080/1 7441692.2012 .729152

Yin, R. K. (1994). Case Study Research: Design and Methods (Applied Social Research Methods, Vol. 5). Sage Publications, Beverly Hills, CA. Rick Rantz Leading urban institutions of higher education in the new millennium Leadership \& Organization Development Journal, $23(8), 2002$.

\section{Author}

Alphonse Kumaza is a senior tourism officer at the Ministry of Tourism, Arts and Culture, Ghana and works with the research and statistics department. He is currently reading for Ph.D. in business administration at the Huazhong University of Science and Technology (HUST), Wuhan, China. His research interests are in corporate social responsibility and corporate governance and policy and governance.

\section{Je politika upravljanja podjetij nova paradigma za družbeno odgovornost? Raziskovalni program iz Gane}

\section{Izvleček}

Družbena odgovornost je bila deležna veliko pripomb glede poslovnih zavez, ki služijo kot nadomestilo za dobičke podjetij in/ali iskanje koristi v gostiteljskih skupnostih. Temeljna komponenta družbene odgovornosti in izboljšanje le-te - politika upravljanja - sta žal prezrta. Prispevek zato priporoča podjetniško politiko za pravično in kompenzacijsko korporativno državljanstvo v lokalnih skupnostih. Da bi utemeljili predlog, v prispevku utemeljujemo, da se lahko družbene odgovornosti izboljšajo s politiko upravljanja, da avtoritativna politika predstavlja odločilno spremembo izvajanja socialnih pobud, in da odsotnost politike spodbuja neučinkovitost izvajanja in premalo zavez. Analiza podatkov s pomočjo programa SPSS kaže, da so koeficienti statistično značilni, kar potrjuje trditev, da politika upravljanja podjetij bogati in pospešuje družbeno odgovornost. Predlagani okvir politike prinaša ne le konkurenčne, znanstvene, objektivne in odlične storitve, temveč predstavlja tudi novost in možnosti za prihodnje raziskave.

Ključne besede: politika upravljanja podjetij, državljanstvo podjetij, družbena odgovornost, eksternalije 